\title{
Development and construction of chambers for metals sintering in special atmospheres
}

\author{
Desenvolvimento e construção de câmaras para sinterização de metais em \\ atmosferas especiais
}

Jorge Magner Lourenço ${ }^{1}$, José de Anchieta Lima1, Kleber José Barros Ribeiro²

\begin{abstract}
Powder metallurgy is a manufacturing process of units in which the raw material comes in its form of power. The microstructural control and technological necessity to produce certain metallic and ceramic components by using this technique has some advantages since the thermal process is done by sintering. The power source commonly used in the sintering process is the resistive oven which can work or not under vacuum. However, in recent decades, the plasma sintering technique has emerged as an alternative heat source. In this technique, heat is provided by the ion bombardment of neutral atoms, electrons, and by the heat radiation generated by this plasma. In this case, in addition to microstructural control by powder metallurgy, sintering aided by plasma favors the atomic sputtering from the cathode material so there will be deposition and consequential atomic diffusion of elements on the substrate of the sintering sample. For the vacuum sintering in the resistive furnace, heat is provided by an electric resistance, however, to avoid metal oxidation it is carried out through a vacuum atmosphere. For both techniques, the chamber is one of the key elements of a vacuum system, particularly, to prevent contamination of the sample and allowing the plasma generation and its maintenance in the temperature process. For the construction of these chambers, attention is required in the specification of the materials involved, surface finishing preparation and welding process to ensure an effective vacuum system. Therefore, this work has as main purpose to report the development of two sintering chambers, which are already in use: (a) one for a vacuum resistive oven; and (b) another one for cold plasma of hydrogen and argon.
\end{abstract}

Keywords: Powder Metallurgy; Sintering; Plasma; Special Atmospheres.

\section{RESUMO}

A metalurgia do pó é um processo de fabricação de peças onde a matéria-prima para formação de determinado componente está na forma de pós. O controle microestrutural e a necessidade tecnológica de se produzir determinado componente metálico e/ou cerâmico por meio desta técnica são algumas das vantagens deste processo, sendo que a consolidação destes componentes é realizada por meio de um tratamento térmico chamado de sinterização. A fonte de energia comumente utilizada no processo de sinterização é o forno resistivo, podendo trabalhar a vácuo ou não. Porém, nas últimas décadas, surgiu uma nova técnica de sinterização, objeto de estudo deste trabalho, que utiliza o plasma como fonte de energia. A técnica de sinterização via plasma, o calor é fornecido pelo bombardeamento de íons, átomos neutros, elétrons e pela própria irradiação térmica gerada por este plasma. Neste caso, além do controle microestrutural auferido pela metalurgia do pó, a sinterização auxiliada pelo plasma favorece a pulverização atômica do material do cátodo fazendo com que haja deposição, e uma conseqüente difusão atômica de elementos de ligas no substrato da amostra sinterizada. Já a sinterização a vácuo em forno resistivo, calor é fornecido pelo aquecimento de uma resistência elétrica, porém, como se trata de sinterização de um componente metálico, a proteção de sua oxidação se dar através de atmosfera de vácuo. Para ambas as técnicas, a câmara é um dos elementos chave do sistema de vácuo, evitando a contaminação da amostra, permitindo a geração do plasma e sua manutenção na temperatura do processo. Para construção destas câmaras, atenção é requerida na especificação dos materiais envolvidos, acabamento superficial e processos de soldagem para garantir um efetivo sistema de vácuo. Portanto, este trabalho tem como principal finalidade mostrar o desenvolvimento de duas câmaras de sinterização: (a) uma para vácuo em forno resistivo; e (b) outra para plasma frio de hidrogênio e argônio.

Palavras-chave:Metalurgia doPó; Sinterização,Plasma; Atmosfera Especial

\footnotetext{
${ }^{1}$ Instituto Federal de Educação, Ciências e Tecnologia do Rio Grande do Norte - Natal (RN) - Brazil

¿Universidade Federal do Rio Grande do Norte - Natal (RN) - Brazil

Correspondence author: Instituto Federal de Educação, Ciências e Tecnologia do Rio Grande do Norte - Av. Sen. Salgado Filho, 1559,

Tirol - CEP 59015-000 - Natal (RN) - Brazil

E-mail: jorge.magner@ifrn.edu.br

Received: 05/08/2015 Approved: 09/12/2015
} 


\section{INTRODUCTION}

Powder metallurgy is a process for obtaining metal components, which occupy a significant share of the world market, especially in the automotive industry. It is a clean process with minimum waste material, good microstructural control and often the only viable technology for processing materials, such as for example, the manufactory of sintered filters, hard metal, and incandescent filaments. This process of obtaining metal components basically comprises of four stages: production, mixing powder, compacting, and sintering. This last step is the most important in the consolidation of a compressed metal, because it is a complex process, especially by the property changes done in the material ${ }^{(1-5)}$.

Several sintering techniques have been developed in recent decades, among them, we can highlight the following: activated sintering; Plasma Activated Sintering (PAS); sintering with discharge using radio frequency or microwave; and in recent decades, the sintering DC plasma discharge. The extensive use of plasmas for treating surfaces is due to its ability to efficiently generate active chemical species to produce ions and accelerate them towards the substrate. The advantage of using such technology is mainly the versatility in the operation process and its reproducibility associated with the economy - time and temperature treatments - obtained, compared to conventional processes. Electrical discharges are widely used in hardening metal surfaces and in the electronic industries by means of industrial processes such as surface cleaning, thin film deposition, processing of microelectronic components, engraving, and the sintering of metal components obtained by powder metallurgy. Ferrous materials obtained by this type of process have been used as structural materials, even with a porous phase. The compensation of the porous phase generally is made from the addition of elements in the volume or only in a surface layer, improving its mechanical and physical properties ${ }^{(6-10)}$. In most industrial applications high hardness components are required to withstand the severe working conditions, especially when it comes to surface wearing - and hardcore properties for shock absorption. Axles in motion transmission are examples of such applications. Another major advantage of this technique is the sintering of compacted metallic with simultaneous introduction of chemical elements ${ }^{(11-14)}$. Starting with the geometric configuration of electrodes, called confined anodecathode, it is possible the extraction of cathode atoms, and their subsequent deposition in the sample, which is the anode electrode of the discharge. This effect is known as sputtering, which occurs due to ion bombardment and fast neutral species in the cathode discharge, formed by the gas mixture of hydrogen and argon. This deposition is performed simultaneously with the sintering process by forming carbides, bainite, and austenite microstructures. The plasma generation is only possible if done at processing pressures, due to an efficient vacuum system. For example, the processing pressure chambers in the development of this project, is between 100 and $1000 \mathrm{~Pa}$ ( 1 to $10 \mathrm{mbar}$ ), which some authors consider medium vacuum ${ }^{(15-16)}$. This is the vacuum level that allows bright electrical discharges, other atomic and molecular phenomenon. The ideal condition is that the vacuum chamber must keep indefinitely, the final vacuum pressure reached during pumping. However, this condition is never achieved since these systems increase their own pressure after being isolated from the pump system. The increased pressure in the vacuum chamber may be caused by the gas outgassing from the walls of the chamber, or desorption permeation by small leaks. Leaks can occur by air input through a small hole within the wall, from small cracks in welded joints, by a radial scratch in the surface of a flange or a sealing slot. One can also have sets of pores, originated from manufacturing processes or oxidation in the welding of the chamber materials. So even for the most efficient system, as more advanced vacuum pumps and the best welded joints process have been used, always there will be a small leak and, consequently, the vacuum pressure will reach a minimum value that cannot be reduced. For building a vacuum system, you need to know the pump very well that will achieve the required pressure, to know how to specify properly the pressure gauge, to know the necessary materials to withstand the effects of vacuum, and finally the material for the sealing system, so that the outside air cannot get in.

Materials that assure the tightness of the vacuum system parts are joints and connections in combination with highly polished metals, metal rings, rubber and special plastics. The materials to be specified for building a vacuum chamber must meet the following conditions: low degassing capacity, low permeability to gases and vapors, low vapor pressure, high corrosion resistance, and high mechanical resistance ${ }^{(16)}$.

A heated material at under a low pressure environment could easily change its phase condition; that is, it can transform directly from solid to gas. In this manner, materials with low vapor pressure and therefore more suitable for the construction of vacuum equipment are glass, copper, aluminum, stainless steel, silver, some plastics and synthetic rubbers ${ }^{(16)}$. Since the vapor pressure is proportional to the temperature, several other materials such as brass or some plastics are acceptable, depending on the expected final pressure and working temperature. Care should be taken with moisture absorbed by the material and other additives used in the manufacture of plastics, the grease used for lubrication and sealing, and even some metals such as mercury, zinc, lead and cadmium.

Another factor that may compromise the effectiveness of the vacuum system is the adsorption that occurs when gases adsorb to the surfaces of these materials. These adsorbed molecules will be desorbed gradually, increasing the pressure of the evacuated environment. The usual procedure for degassing surfaces is to bake the equipment, maintaining the vacuum pump functioning during this process. The heat causes the molecules to desorb from the surface and then pumped. Porous, fibrous, or powder 
materials should be avoided inside the vacuum chamber, as they have large surface areas capable of adsorbing large amounts of gas.

Therefore, the main objective of this work is the construction of two vacuum chambers for sintering metals: one uses plasma as a source of energy in the sintering process and another uses a vacuum resistive oven.

\section{MATERIALS AND METHODS}

\section{Materials used in the construction of the vacuum chamber}

The selected material for construction of the vacuum chambers is in accordance with the requirements in use for medium vacuum, as the list shown in Table 1.

\section{Construction of plasma sintering chamber}

The chamber for plasma sintering was built in a cylindrical shape using austenitic stainless steel AISI 316 approximately $250 \mathrm{~mm}$ in diameter and $300 \mathrm{~mm}$ in height, as shown in Fig. 1. A viewing window was cut into the cylindrical body of the chamber to allow observing the electrical discharge during execution of the sintering process. This window was threaded allowing a borosilicate circular glass being inserted within a rubber O-ring for vacuum insulation. For economic reasons all of the austenitic materials of this chamber were purchased from recycling metal companies, both in the form of tubes and in the form of a flat plate.

The covers, upper and lower, of this chamber were built also with austenitic stainless steel AISI 316 plates $8 \mathrm{~mm}$ thick, as shown in

Table 1: Materials used in vacuum systems.

\begin{tabular}{|c|c|}
\hline Materials & Characteristics \\
\hline Austenitic stainless steel AISI 316 & $\begin{array}{l}\text { It has a very long service life; high resistance to corrosion and chemical attack; in modern is the most } \\
\text { used metal; low vapor pressure; low permeability; high mechanical strength and easy welding. }\end{array}$ \\
\hline Austenitic stainless steel AISI 310 & $\begin{array}{l}\text { It has a high resistance to corrosion and chemical attack at high temperatures, due to the effect } \\
\text { produced by increasing the nickel content. }\end{array}$ \\
\hline Borosilicate glass (Pyrex) & In general, have good mechanical strength and can be degassing under vacuum to $450^{\circ} \mathrm{C}$. \\
\hline Teflon Polytetrafluoroethylene - PTFE & $\begin{array}{l}\text { It is quite expensive but is the best type of plastics for use in vacuum; applies in sealing rings and } \\
\text { diaphragms, valves; prolonged use may lose elasticity and cause leaks; used as electrical insulator; } \\
\text { can be used up to } 300^{\circ} \mathrm{C} \text { without any problem and has low vapor pressure. }\end{array}$ \\
\hline Natural Rubber & It is used in the connecting pipes of the pumps, with the drawback of being attacked by oils and fats. \\
\hline Nitrile Rubber. & $\begin{array}{l}\text { More resistant to oils than neoprene and natural rubber, having lower permeability and degassing; } \\
\text { maximum temperature supported at rest is } 150^{\circ} \mathrm{C} \text { and } 80^{\circ} \mathrm{C} \text { in vacuum; widely used as O-rings. }\end{array}$ \\
\hline Silicon & Quite resistant to high temperatures and can be used up to $200^{\circ} \mathrm{C}$. \\
\hline
\end{tabular}
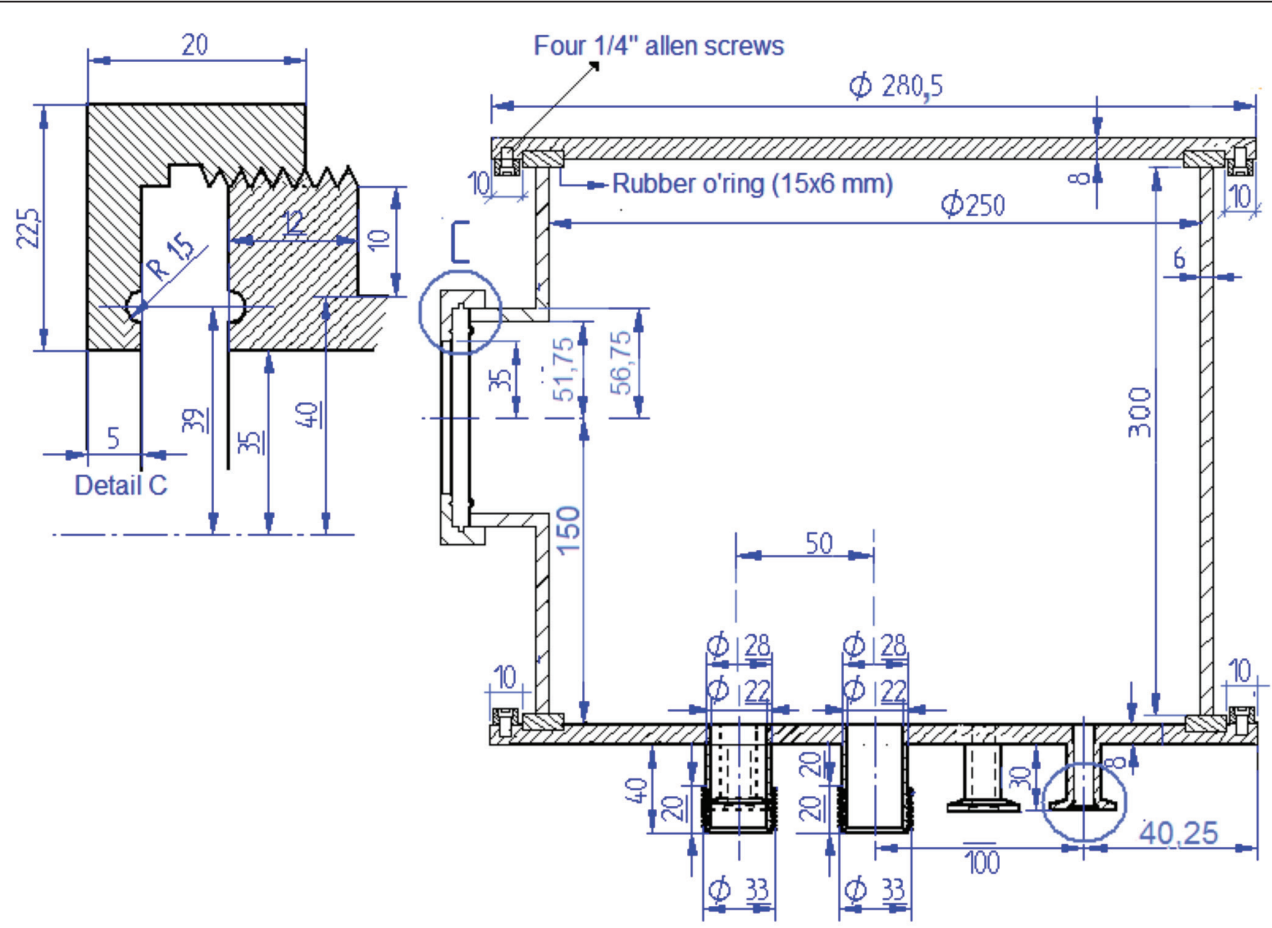

Figure 1: Plasma sintering chamber with details and dimensions. 
Fig. 2. Five holes of $15.5 \mathrm{~mm}$ diameter were adapted in the bottom cover of the chamber for the type connections NW 16 for easy attachment, and rubber O-rings and clamps were used for sealing and vacuum insulation, as shown in detail $\mathrm{C}$ of Fig. 2. These holes were distributed in a radius of $100 \mathrm{~mm}$ and spaced $60^{\circ}$, being used for entry of gases, vacuum pump coupling, pressure sensor adaptation, and feedthrough for a type $\mathrm{K}$ thermocouple.

The diameter of the hole to access the vacuum pump should not be too small in order to pump effectively, because when working with medium and high vacuum it is very difficult to remove the residual gas with thin tubes. Besides this molecular gas behavior, the pressure difference between the vacuum chamber and the vacuum created within the pump is too small. The resistance of the pipe to the passage of gas becomes of crucial importance in lowering the pressure. The final pumping should be done through wide and short tubes.

Another two holes of $28 \mathrm{~mm}$ diameter were perforated in the lower cover: one in the center and the other at $180^{\circ}$, a further $50 \mathrm{~mm}$ away, used as feedthroughs of the two electrodes used in an electric charge - the cathode and the anode. The vacuum sealing and insulation between the caps and the cylindrical body of the chamber was made with a high temperature silicone rubber, laid down in the channel cover slot of the $15 \times 3 \mathrm{~mm}$.

In Fig. 3 details of an electrode and its components are shown. The electrodes were made of austenitic stainless steel AISI 316, and in the cathode a $2 \mathrm{~mm}$ hole in diameter was made throughout its length. This allows the passage of a type $\mathrm{K}$ thermocouple $1.5 \mathrm{~mm}$ in diameter protected also with a stainless steel and

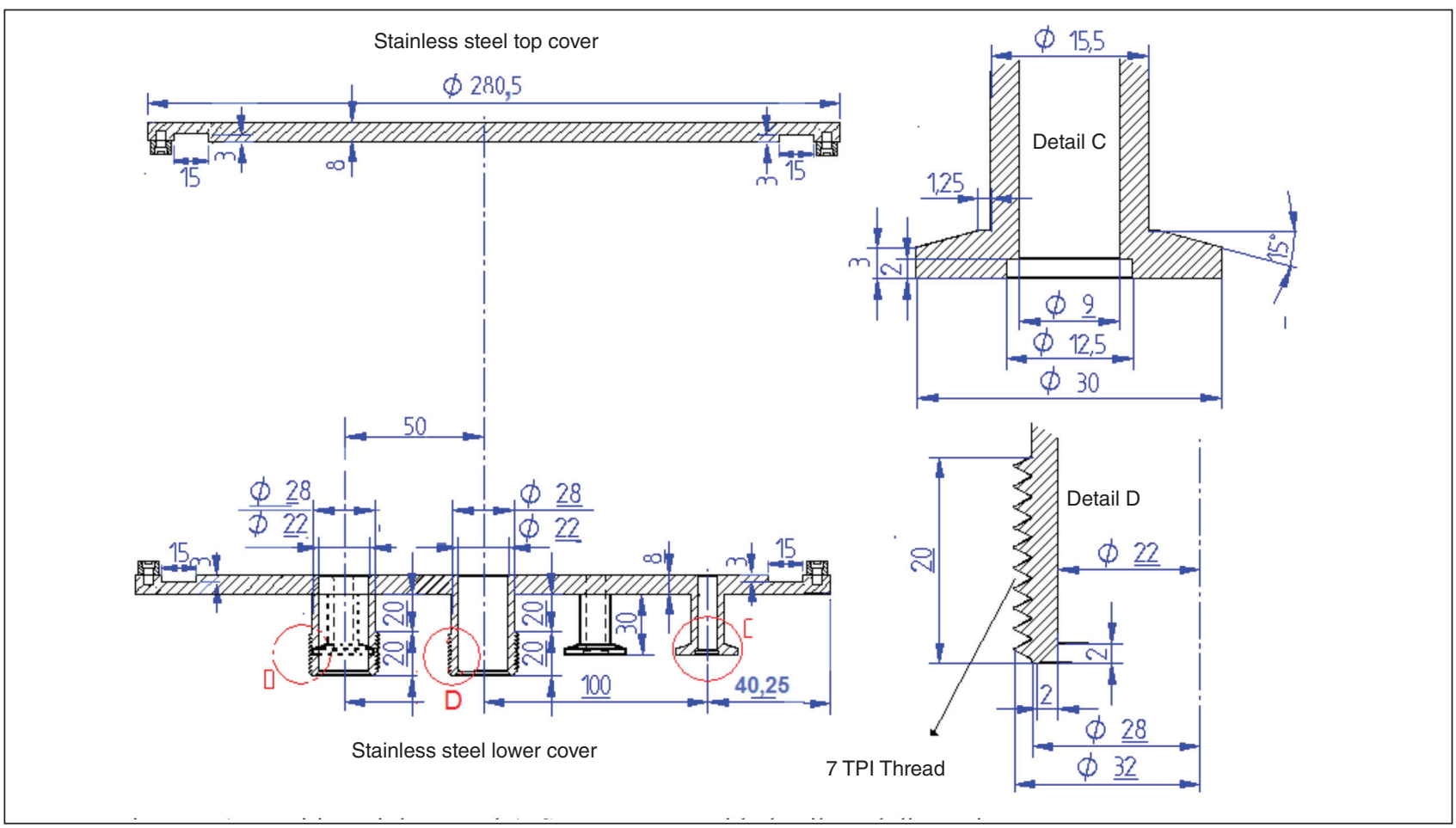

Figure 2: Austenitic stainless steel AISI 316 covers with details and dimensions.

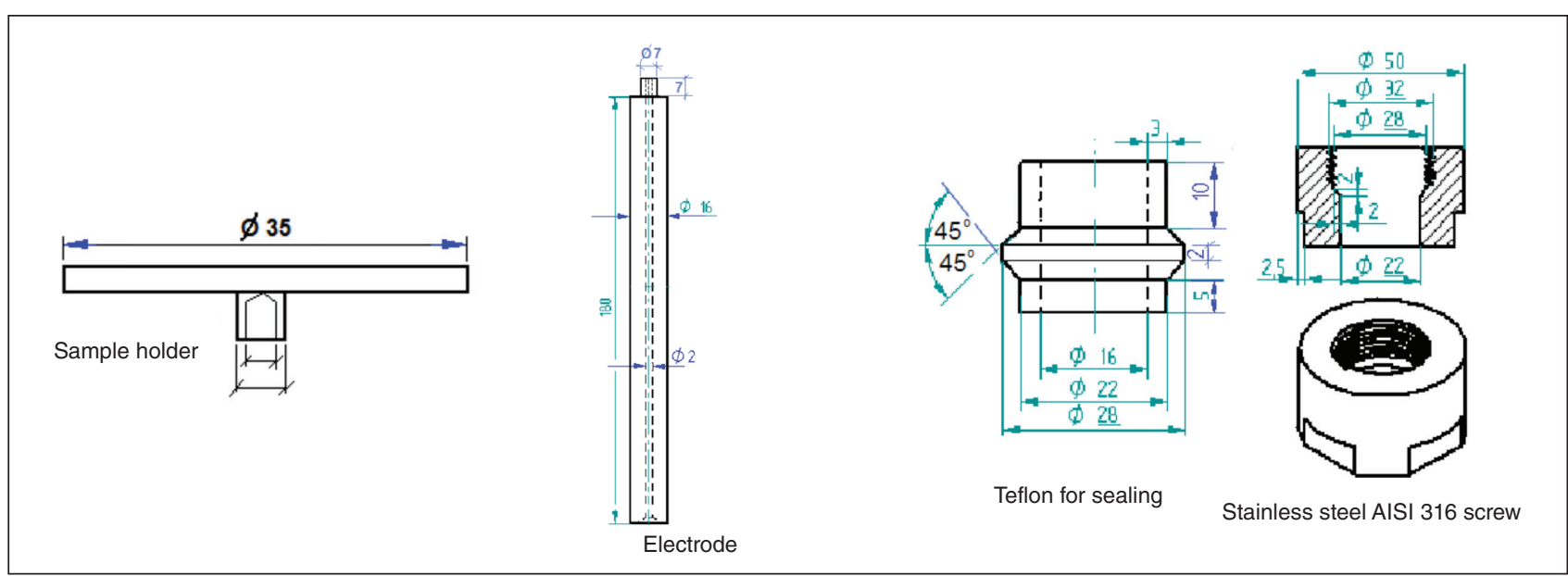

Figure 3: Electrode and sealing components details. 
electrically insulated with $\mathrm{Al}_{2} \mathrm{O}_{3}$. The two electrodes were inserted into the central hole of the lower cover and tightened by a nut with a coarse Whitworth thread with seven threads per inch, see detail $\mathrm{D}$ of Fig. 2. For guaranteeing insulation and vacuum sealing, an industrial Teflon component with the same dimensions of the holes and electrodes were used, placed inside the nut, through its internal bore by the electrode, which consequently suffered by tightening deformation, resulting in the sealing of the vacuum.

\section{Construction of the sintering chamber for resistive furnace}

Figure 4 shows the vacuum chamber for sintering in a resistive furnace. Since it will withstand a working temperature in the $1150^{\circ} \mathrm{C}$ range, applied directly on its outer wall, this tube was made of austenitic steel AISI $310^{(17)}$. The stainless tube, purchased from Salaberga Steel Commercial Ltd Company, was bonded and sewn, and at one end was closed by a cap made of the same material. It was $1250 \mathrm{~mm}$ in length and $75 \mathrm{~mm}$ of internal diameter, with the primary purpose of sintering in a vacuum when inserted in a resistive furnace of the horizontal shaft type.

The other end of the tube had a removable lid attached to a flange on the tube using a rubber O-ring and three-butterfly screw type with easy handling. The tube had two lids to be used in accordance with the type of atmosphere sintering. One of these lids had only one entry for a $3.0 \mathrm{~mm}$ diameter type $\mathrm{K}$ thermocouple protected with a stainless steel and electrically insulated with $\mathrm{Al}_{2} \mathrm{O}_{3}$. Since the other, in addition to thermocouple input, had two other holes with a $1 / 4$ inch diameter for insertion of the gases used in the process. These holes were capillary tubes welded austenitic stainless steel AISI 316 with a $1 / 4$ inch diameter, with the goal to achieve a good position on the compacted metal that will meet at the end of the tube, that is, in its hot zone. Connections for gas entry were the type NW 16 for easy attachment, and used rubber o-rings and clamps for sealing and vacuum insulation. In the cold zone of the tube were welded three type NW connection 16 for easy attachment of the pressure sensor and vacuum pump. The third connection was spare for another purpose, and therefore all construction details are shown in Fig. 4.

\section{Procedures to verify the vacuum system efficiency}

When a chamber has a leak, it should be considered if it can be used as a vacuum chamber. If the leak is small and not stopping the working pressure in reasonable time, there will be no need to spend time and effort to find where the leak is or how to fix it. If the desired final pressure is not reached in the vacuum chamber, it can be due to holes or dirt, the pump can be damaged, or the vacuum meter can be defective. However, if this pressure is reached after a long pumping time, this may be due to dirt inside the chamber, the pumping line may be blocked, the pump can be dirty or with low working efficiency. Looking for the source of the problem, whenever it is possible, separate the chamber and pumping system and look for leaks and contamination with increasing pressure. If determined that the chamber is free from defects, the measurement and pumping system will be respectively inspected.

\section{RESULTS AND DISCUSSION}

\section{Plasma sintering chamber}

The images of Fig. 5a, b, c and d are, respectively, the plasma sintering chamber ready to use, the chamber body with a viewing window, top and lower covers. The finishing surface, internal and external, are important in a plasma chamber, because if you need a vacuum around $10 \mathrm{mTorr}(1,33 \mathrm{~Pa})$ prior to the plasma sintering

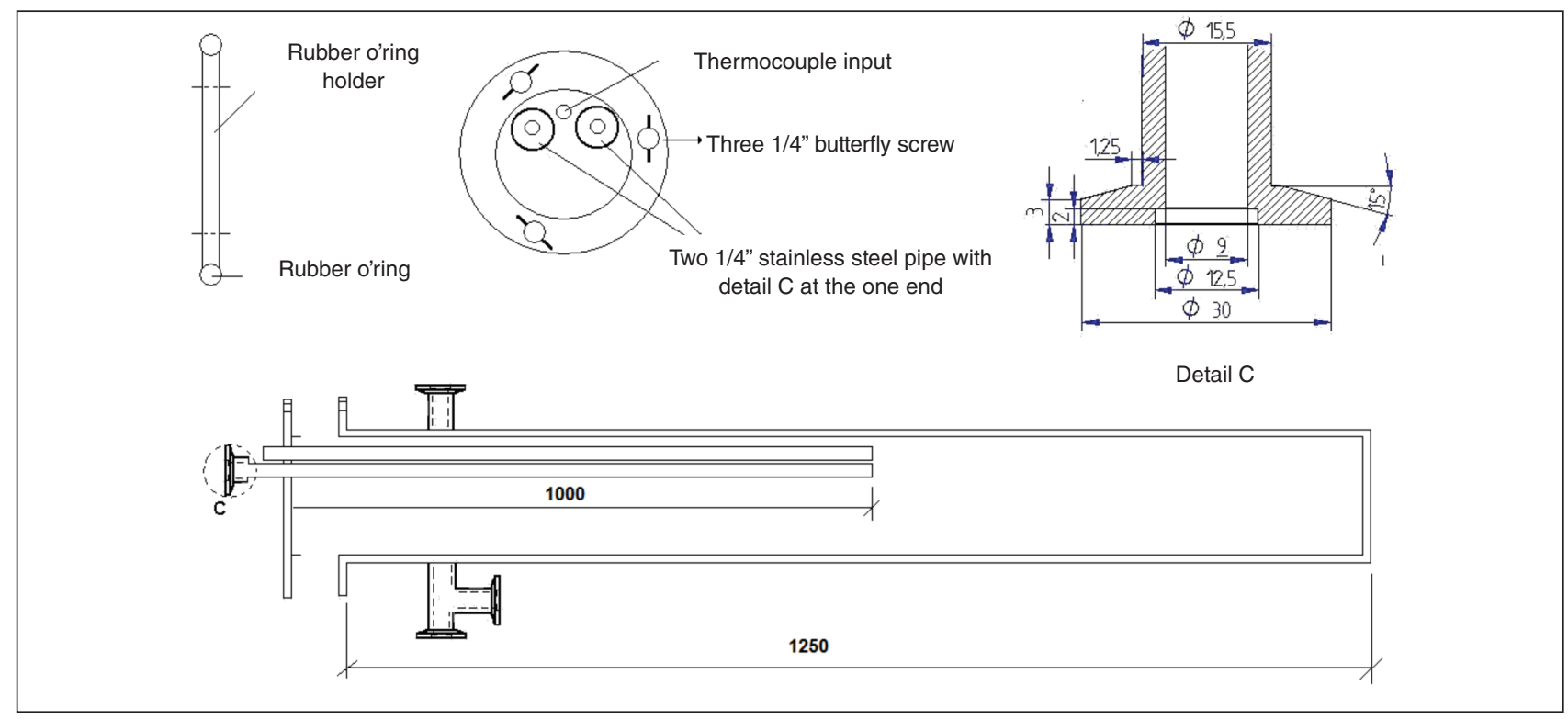

Figure 4: Vacuum chamber for metals sintering in resistive oven. 
process, it will reach. For this situation, it needs a polished surface, especially in its inner wall. The AISI 316 austenitic stainless steel specified for this chamber was adequate in terms of manufacturing process, with high corrosion resistance and good machinability. The welding process used was TIG (Tungsten Inert Gas) with no overlapping layers preventing the formation of oxides and residues including the point of care to avoid dirt accumulation otherwise these can be sources for the degassing process.

It is known that a vacuum chamber will never be perfectly sealed, therefore its isolation is carried out with a pumping system, the pressure will always increase with a higher or lower speed depending on the leaking, requiring the detection of these points during the building and assembling of the equipment. The leaks can appear more easily in the welded points and in the local detachable connections but it may also appear due to pores or fractures in the walls of the system. Another factor that may compromise the vacuum is degassing from the walls and connectors for sealing, and the higher the vapor pressure of these products, the higher is its degassing.

Figure 6 shows the curve for leaks and integrity test for the plasma chamber, basically, determined by the pressure curve versus time. This test was performed as follows: (1) pumping was done for 15 minutes reaching a level of pressure around 90 mTorr (11.999 Pa). This pressure is used for cleaning the chamber prior to the plasma sintering process; (2) the chamber was isolated by closing the valve which connects with the pump; (3) the pump was turned off and the vacuum was tested; and lastly (3) the pressure was measured with time $\mathrm{e}^{(18-19)}$.

Considering that after approximately 120 minutes the vacuum pressure was $400 \mathrm{mTorr}(53.32 \mathrm{~Pa})$. This level of pressure is suitable for plasma sintering process so that the plot shown in Figure 6 is adequate for this kind of metallurgical process. There was a departure from the experimental curve of the system in relation to the theoretical curve showing that the pressure increases with the time due to the degassing of impurities contained on the walls of the chamber, as can be seen in Figure $6^{(17)}$. If this same curve approaches the base line, there would be tiny air leaks coming from inside or outside the chamber, where the equilibrium would be at atmospheric pressure. In each case, sintering would be unfeasible.
Another factor that can be considered, is the effectiveness in the application of silicone O'rings on the sealing system, since the degassing from these O'rings does not compromise the vacuum for the sintering process ${ }^{(20-21)}$.

\section{Sintering chamber on resistive oven}

Figure 7 shows a vacuum sintering chamber ready to be used in a horizontal resistive furnace with the details of the AISI 310 austenitic stainless tube, its inputs to the vacuum pump, pressure sensor and thermocouple. The temperature reached by this tube during the sintering process is $1150{ }^{\circ} \mathrm{C}$ and requires corrosion resistant materials for such conditions. The specification of this

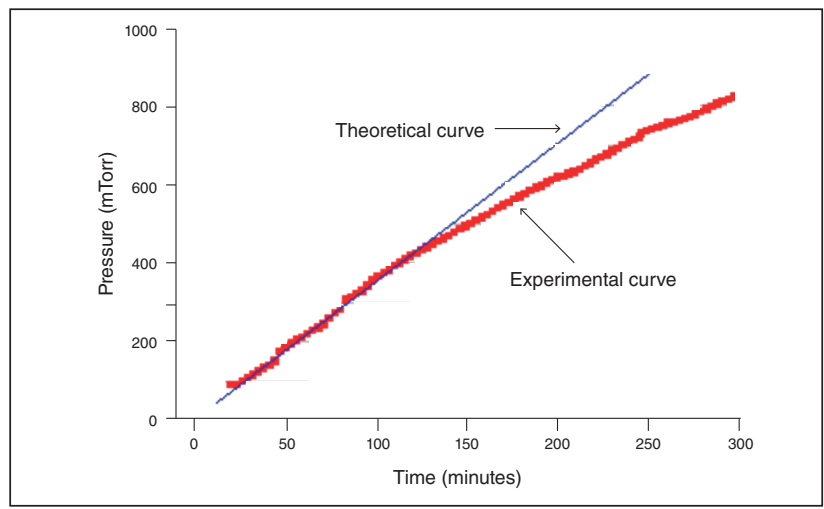

Figure 6: Experimental pressure curve in comparison to theoretical curve (leaks and integrity test).

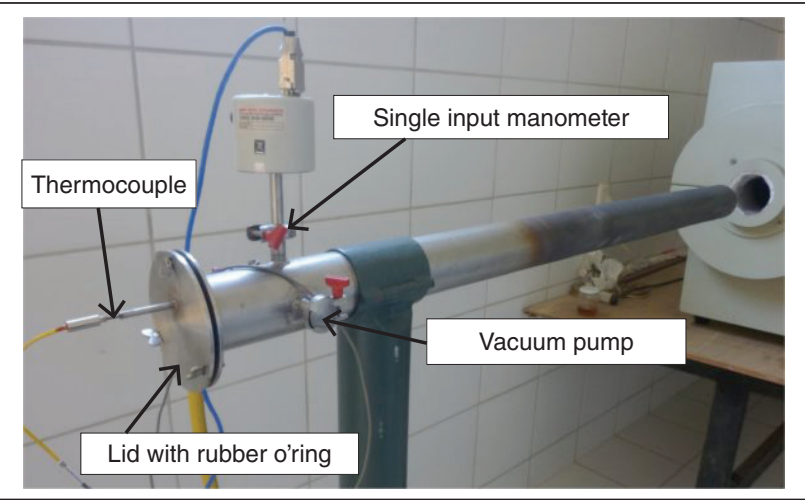

Figure 7: Vacuum sintering chamber for resistive oven.
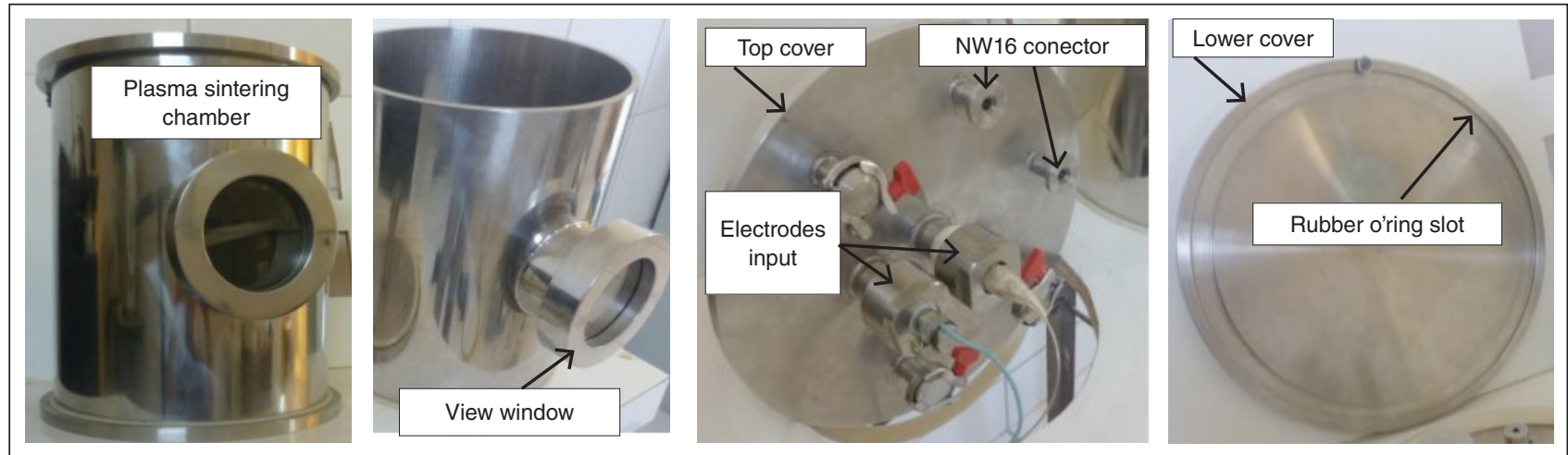

Figure 5: Plasma sintering chamber (a), chamber body (b), lower cover and details (c) and top cover (d). 
material is due to the high stability of the martensite achieved by increasing the nickel content of around 25\%, so that it has high resistance to intergranular corrosion (17). It is worth pointing out that the AISI 316 stainless austenitic steel for the plasma chamber was chosen for economic reasons, since the temperatures reached on the inner surface of its walls are well below $1150{ }^{\circ} \mathrm{C}$.

Compacted samples of different metals were sintered by this vacuum sintering system using the resistive furnace as a heat source. The images in Figure $8 \mathrm{a}, \mathrm{b}$ and $\mathrm{c}$ are, respectively, cast iron $+25 \%$ bronze, cast iron $+1.5 \% \mathrm{Ni}+1.5 \% \mathrm{Mo}$, and unalloyed cast iron. The cast iron plus alloyed powder components were mixed with $0,6 \%$ wt of zinc stearate and compacted to a pressure of $500 \mathrm{MPa}$ using a double action press with moving die body. The samples with $9.5 \mathrm{~mm}$ in diameter and $6 \mathrm{~mm}$ in high are shown in Figure 8. The upper rows of each image are the samples as compacted, and the lower are the same samples as sintered. No sintered specimens were oxidized after the sintering treatment, indicating that the vacuum obtained by the system shown in

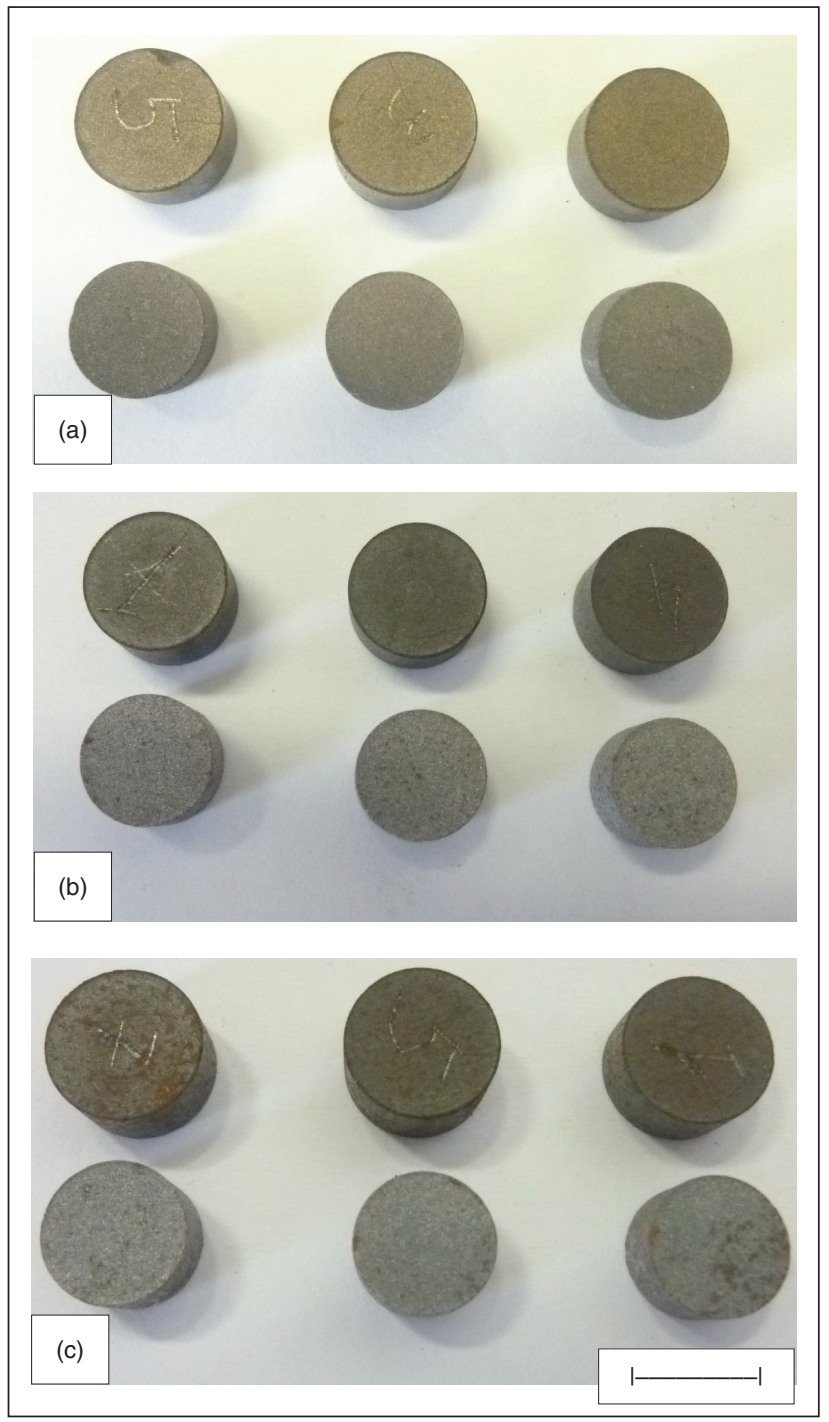

Figure 8: Cast iron $+25 \%$ bronze (a) Cast iron $+1.5 \% \mathrm{Ni}+1.5 \% \mathrm{Mo}$ (b) and cast iron (c). Scale $15 \mathrm{~mm}$.
Fig. 7 was very low. The sintering process was performed at $1150{ }^{\circ} \mathrm{C}$ for 1 hour at a vacuum of $120 \mathrm{mTorr}(15.999 \mathrm{~Pa})$. Details about microstructure development of these samples are being investigated for further publication.

\section{CONCLUSIONS}

In this work, we reported on the selection of materials used in vacuum technology, adapting them to the needs of the vacuum chamber design. The vacuum chamber has reached the required pressure of $10^{-2} \mathrm{mbar}$, holding the system free of contaminants for an acceptable time of 20 minutes. These results indicate that leaks and integrity tests are appropriate to the requirements of the sintering process. The vacuum chamber using the resistive furnace proved feasible for sintering compacted metals powder components, with no surface oxidation in the samples. This shows that the procedures performed during construction were efficient.

\section{ACKNOWLEDGEMENTS}

This work was produced with funds from the Research Support of Rio Grande do Norte Foundation - FAPERN / CNPq.

\section{REFERENCES}

1. ZAPATA, W. C. Estado atual da metalurgia do pó. ABM Associação Brasileira de Metalurgia e Materiais, vol. 43, p.880890, 1987.

2. UPADHYAYA, A.; FUJIKI, A. Industrial PM research in good shape in Japan. Metal Powder Report, Oxford, Janeiro, 2000. p.24-28.

3. GERMAN, R.M. Sintering Theory and Practice. Toronto: Wiley Interscience, 1996. $550 \mathrm{p}$

4. THUMMLER, F.; OBERACKER, R. An Introduction to Powder Metallurgy. Great Britain: The institute of Materials, 1993. 332p.

5. GERMAN, R. M. Powder metallurgy science. $2^{\text {nd }}$. Ed. Princeton, New Jersey: Metal Powder Industries Federation, 1994. 472p.

6. UPADHYAYA, D. D. Microwave sintering of cubic zirconia. Ceramics International, v. 27, p. 415-418, 2001.

7. MATSUMOTO, A.; KATOH, K.; ANDOH, K. Research and development of novel materials by plasma discharge sintering process. Corrosion Engineering, v. 44, p.751-766, 1995

8. LOURENÇO, J. M.; MALISKA, A. M; KLEIN, A. N. The effect of pulse and voltage on unalloyed iron surface during sintering on the cathode of glow discharge. Revista Brasileira de Aplicações de Vácuo, v. 28, n. 3-4, p.59-64, 2009.

9. LOURENÇO, J. M.; H. C. PAVANATI; MALISKA, A. M; KLEIN, A. N. Plasma sintering of unalloyed iron: influence of electrode geometry. Revista Brasileira de Aplicações de Vácuo, v. 27, n. 4, p.205-210, 2008

10. PAVANATI, H. C.; LOURENÇO, J. M.; MALISKA, A. M; KLEIN, A. $N$. Ferrite stabilization induced by molybdenum enrichment in the surface of unalloyed iron sintered in an abnormal glow discharge. Applied Surface Science v.253, p.9105-9111, 2007. 
11. LOURENÇO, J. M. Evolução microestrutural de ferro puro e ligas ferrosas sinterizadas por plasma. 2004.149f. Tese de Doutorado - Departamento de Engenharia Mecânica, Universidade Federal de Santa Catarina, Florianópolis.

12. BATISTA, J. V.; BINDER, R.; KLEIN, A. N.; MUZART, J. L. R. Sintering iron using an abnormal glow discharge. The International Journal of Powder Metallurgy, v. 34, n 8, p. 55-61, 1998.

13. PAVANATI, H. C. ; MALISKA, A. M. ; KLEIN, A. N. ; MUZART, J. L. R . Sintering unalloyed iron in abnormal glow discharge with superficial chromium enrichment. Materials Science \& Engineering. A, Structural Materials: properties, microstructure and processing, Shannon, v. 392, n. 1-2, p. 313-319, 2005.

14. RIBEIRO, K. J. B. Nitretação em plasma com gaiola catódica: caracterização e avaliação do desempenho da camada nitretada em facas de corte. 2007. 92f. Dissertação de mestrado. Programa de Pós-Graduação em Ciências e Engenharia de Materiais. UFRN, Natal.
15. BARANOWSKAA, J.; KUSIORB, E.; AMIGOC, V.; SZCZECIN'SKIA K. Surface modification of austenitic steel by low-temperature plasma. Vacuum, v.78, p.389-394, 2005.

16. YANHUA, L.; HONGYAN, Y.; JINKU, W. Development of vacuum metrology in National Institute of Vacuum, v.86, p.903-907, 2012.

17. DIETER, G. E. Mechanical Metallurgy. McGraw-Hill Book Co (UK), 1988. 749p.

18. STEMPNIAK R. A. A ciência e a tecnologia do vácuo resumo histórico e algumas aplicações. Sociedade Brasileira de Vácuo. 2002.

19. MOUTINHO, A.M.C. et al., Tecnologia do Vácuo, Lisboa, Universidade de Lisboa, 1980.

20. MIYAHARA, A. Overview on new materials for vacuum techniques Vacuum, v.41, n.7-9, p.866 to 1869,1990

21. ALEXANDER, R. Vacuum technology. Elsevier Science B. V. Third edition. Amsterdam, Netherlands, 1990. 